This is the peer reviewed version of the following article: Reis FS, Barreira JCM, Calhelha RC, van Griensven LJID, Ćirić A, Glamočlija J, Soković M, Ferreira ICFR. Chemical characterization of the medicinal mushroom phellinus linteus (berkeley \& curtis) teng and contribution of different fractions to its bioactivity. LWT - Food Sci Technol. 2014;58(2):478-85.http://dx.doi.org/10.1016/j.lwt.2014.04.013.

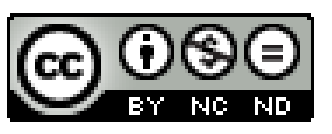

(C) 2014 Elsevier Ltd. 


\title{
Chemical characterization of the medicinal mushroom Phellinus linteus (Berkeley \& Curtis) Teng and contribution of different fractions to its bioactivity
}

\author{
FiliPA S. ReIs ${ }^{\mathrm{a}}$, JoÃo C.M. BARREIRA ${ }^{\mathrm{a}}$, RICARdo C. CALHELHA ${ }^{\mathrm{a}}$, LEO J.I.D. VAN \\ GRIENSVEN $^{c}$, ANA ĆIRIĆ $^{\mathrm{b}}$, JASMINA GLAMOČLIJA $^{\mathrm{b}}$, MARINA SOKOVIĆ ${ }^{\mathrm{b}, *}$ \\ ISABEL C.F.R. FERREIRA, ${ }^{\mathrm{a}, *}$
}

\begin{abstract}
${ }^{a}$ Mountain Research Center (CIMO), ESA, Polytechnic Institute of Bragança, Campus de Santa Apolónia, Ap. 1172, 5301-855 Bragança, Portugal.

${ }^{\mathrm{b}}$ University of Belgrade, Department of Plant Physiology, Institute for Biological Research “Siniša Stankovič”, Bulevar Despota Stefana 142, 11000 Belgrade, Serbia. ${ }^{c}$ Plant Research International, Wageningen University and Research, P.O. Box 16, 6700 AA Wageningen, The Netherlands.
\end{abstract}

\footnotetext{
* Authors to whom correspondence should be addressed (Isabel C.F.R. Ferreira; e-mail: iferreira@ipb.pt; telephone +351-273-303219; fax +351-273-325405 and Marina D. Soković; e-mail: mris@ibiss.bg.ac.rs; telephone +381-11-2078419; fax +381-112761433).
} 


\begin{abstract}
Mushrooms are widely appreciated for their organoleptic qualities, being also recognized as good sources of bioactive compounds that provide antioxidant, antimicrobial and cytotoxic activities. Polysaccharides (including glucans) are often pointed out as the most bioactive compounds isolated from mushrooms, but other molecules such as triterpenoids, might also be highlighted for their bioactivity. In scientific research, when isolated compounds are used, potential synergistic effects might be lost. Accordingly, the bioactivity of $P$. linteus was evaluated in selected fractions (polysaccharides, glucans and triterpenoids), as well as in the methanolic and ethanolic extracts. The best antioxidant and antibacterial activities were obtained with methanolic extract, while glucan and triterpenoid fractions gave the strongest antifungal activity. In contrast, ethanolic extract gave the best results in cytotoxic activity, indicating that the bioactive compounds present might act synergistically. The differentiated activity of $P$. linteus fractions and extracts could be useful to find antimicrobial, antioxidant and cytotoxic agents as alternatives to synthetic chemicals with application in agriculture, food industry or pharmacy.
\end{abstract}

Keywords: Phellinus linteus; bioactive compounds; antioxidant; antimicrobial; cytotoxic. 


\section{Introduction}

Wild mushrooms contain different bioactive compounds such as phenolic compounds, tocopherols and ascorbic acid, which could be extracted for the purpose of being used as functional ingredients namely against chronic diseases related to oxidative stress. Also, mushrooms might be used directly in diet and promote health, taking advantage of the additive and synergistic effects of their bioactive compounds (Ferreira, Barros, \& Abreu, 2009).

Phellinus linteus, originally described as Polyporus linteus (Kim, Kim, Sung, \& Harrington, 1999), belongs to the Hymenochaetaceae family (Basidiomycetes) and has long been used for the treatment of stomachache, inflammation, arthritis of the knee, gastrointestinal disorder, non-insulin-dependent diabetes, lymphatic disease and cancer (Huang et al., 2011; Kim et al., 2004a). It was previously described as immunomodulatory (Wu, Liaw, Pan, Yang, \& Ng, 2013), neuroprotective (Chen, Feng, Huang, \& Su, 2012), antitumor (Zhu et al., 2007; Huang et al., 2011; Song et al., 2011), anti-hepatotoxic (Kim et al., 2004b), antioxidant (Ferreira et al., 2009), anti-angiogenic and anti-inflammatory (Kim et al., 2004a). P. linteus was also reported as having antimicrobial activity, especially against Bacillus cereus and methicillin-resistant Staphylococcus aureus (Alves et al., 2012; Hur et al., 2004). Several P. linteus secondary metabolites were previously isolated like lectines, triterpenes (Maiti et al., 2010), meshimakobnols A and B (Nagatsu et al., 2004), hispidin (Lee et al., 2008; Chen et al., 2012), davallialactone, methyldavallialactone, hypholomine B, interfungins A, inoscavin A, protocatechuic acid, protocatechualdehyde, caffeic acid, ellagic acid (Lee et al., 2008), and also phellifuropyranone A, phelligridin G (Kojima, Ohno, Inoue, Mizukami, \& Nagatsu, 2008) and phelligridimer A (Lee et al., 2008). Nevertheless, polysaccharides (particularly $\beta$-D-glucans and polysaccharopeptides (PSP)) are the best 
known and most potent mushroom-derived substances with antitumor and immunomodulating properties, stimulating humoral and cell-mediated immunity (Ferreira, Vaz, Vasconcelos, \& Martins, 2010; Maiti et al., 2010; Heleno et al., 2012).

The biological activities of triterpenoids are also relevant, progressively receiving more attention in the biochemical and medical fields due to their immunomodulatory and antitumor effects (Tu, Sun, \& Ye, 2008).

Herein, the composition in hydrophilic (free sugars, organic acids and phenolic acids) and lipophilic (ergosterol, tocopherols and fatty acids) compounds was evaluated in $P$. linteus, as well as their antioxidant, antibacterial and antifungal properties, and cytotoxicity in human tumor cell lines. Instead of evaluating individual compounds, the whole methanolic and ethanolic extracts as also different fractions (polysaccharides, glucans and triterpenoids) were used, allowing evaluating potential synergistic activities.

\section{Material and Methods}

\subsection{Samples, extract and fractions preparation}

Crude material (dry fruiting body) and crude fractions of polysaccharides and triterpenoids of wild Phellinus linteus are commercial food supplements and were kindly provided by Amazing Grace Health Industries (Bangkok, Thailand). Glucans were semi purified from $P$. linteus polysaccharides as described before (Song, Helsper, \& Van Griensven, 2008) by repeated precipitation in $65 \%$ ethanol to remove the excess mannitol and ethanol-soluble phenolic compounds. The precipitate was dried at $42^{\circ} \mathrm{C}$, in vacuum and stored for further use. 
The methanolic extract was obtained by stirring the dry fruiting body $(1 \mathrm{~g})$ with $40 \mathrm{~mL}$ of methanol for $1 \mathrm{~h}$ and subsequently filtered through Whatman No. 4 paper. The residue was then extracted with $20 \mathrm{~mL}$ of methanol for $1 \mathrm{~h}$. The combined methanolic extracts were evaporated at $40^{\circ} \mathrm{C}$ (rotary evaporator Büchi R-210) to dryness.

The ethanolic extract was obtained from dry fruiting body by extraction with $90 \%$ ethanol during $48 \mathrm{~h}$ at $70^{\circ} \mathrm{C}$. The extract (probably rich in triterpenoids and polyphenols) was filtrated and centrifuged to get a clear liquid, and finally evaporated at low pressure at $40^{\circ} \mathrm{C}$.

\subsection{Standards and reagents}

Acetonitrile $99.9 \%, n$-hexane $95 \%$ and ethyl acetate $99.8 \%$ were of HPLC grade from Fisher Scientific (Lisbon, Portugal). The fatty acids methyl ester (FAME) reference standard mixture 37 (standard 47885-U) was purchased from Sigma (St. Louis, MO, USA), as also other individual fatty acid isomers and standards of tocopherols, ergosterol, sugars, organic acids and phenolic compounds, and trolox (6-hydroxy2,5,7,8-tetramethylchroman-2-carboxylic acid). Racemic tocol, $50 \mathrm{mg} / \mathrm{mL}$, was purchased from Matreya (PA, USA). 2,2-Diphenyl-1-picrylhydrazyl (DPPH) was obtained from Alfa Aesar (Ward Hill, MA, USA). Mueller-Hinton agar (MH) and malt agar (MA) were obtained from the Institute of Immunology and Virology, Torlak (Belgrade, Serbia). Dimethylsulfoxide (DMSO), (Merck KGaA, Germany) was used as a solvent. Phosphate buffered saline (PBS) was obtained from Sigma Chemical Co. (St. Louis, USA). Foetal bovine serum (FBS), L-glutamine, Hank's balanced salt solution (HBSS), trypsin-EDTA (ethylenediamine tetraacetic acid), nonessential amino acids solution $(2 \mathrm{mM})$, penicillin/streptomycin solution $(100 \mathrm{U} / \mathrm{mL}$ and $100 \mathrm{mg} / \mathrm{mL}$, respectively), RPMI-1640 and DMEM media were from Hyclone (Logan, USA). Acetic 
acid, ellipticine, sulforhodamine B (SRB), trypan blue, trichloroacetic acid (TCA) and Tris were from Sigma Chemical Co. (Saint Louis, USA). Methanol and all other chemicals and solvents were of analytical grade and purchased from common sources. Water was treated in a Milli-Q water purification system (TGI Pure Water Systems, USA).

\subsection{Chemical characterization of Phellinus linteus}

\subsubsection{Macronutrients}

The samples were analysed for chemical composition (moisture, proteins, fat, carbohydrates and ash) using the AOAC procedures (AOAC, 1995). The crude protein content $(\mathrm{N} \times 4.38)$ of the samples was estimated by the macro-Kjeldahl method; the crude fat was determined by extracting a known weight of powdered sample with petroleum ether, using a Soxhlet apparatus; the ash content was determined by incineration at $600 \pm 15^{\circ} \mathrm{C}$. Total carbohydrates were calculated by difference. Energy was calculated according to the following equation: Energy $(\mathrm{kcal})=4 \times(\mathrm{g}$ protein $+\mathrm{g}$ carbohydrate $)+9 \times(\mathrm{g}$ fat $)$.

\subsubsection{Hydrophilic compounds}

Free sugars. Sugars were analysed by high performance liquid chromatography (HPLC) using a refraction index (RI) detector. This assay was conducted according to a previously described methodology (Reis et al., 2013).

Organic acids. Organic acids were analyzed by ultra-fast liquid chromatography (UFLC) coupled to a photodiode array detector (PDA) following a previously described procedure (Reis et al., 2013). The organic acids were quantified by comparison of the 
peak area recorded at $215 \mathrm{~nm}$ with calibration curves calculated from commercial standards of each compound. The results were expressed in g per $100 \mathrm{~g}$ of dry weight.

Phenolic acids. The analysis was performed by the same HPLC equipment described for organic acids, according to a previously described procedure (Reis et al., 2013). Detection was carried out in a PDA using $280 \mathrm{~nm}$ as the preferred wavelength.

\subsubsection{Lipophilic compounds}

Fatty acids. Fatty acids were determined by gas-liquid chromatography with flame ionization detection (GC-FID)/capillary column as described previously (Reis et al., 2012a). Split injection (1:40) was carried out at $250^{\circ} \mathrm{C}$. Fatty acids identification was made by comparing the relative retention times of FAME peaks from samples with standards. The results were recorded and processed using the Clarity DataApex 4.0 Software and expressed in relative percentage of each fatty acid.

Tocopherols. The analysis were carried out using the HPLC equipment described above coupled to a fluorescence detector (FP-2020; Jasco) programmed for excitation at 290 $\mathrm{nm}$ and emission at $330 \mathrm{~nm}$ according to a previously described methodology (Heleno, Barros, Sousa, Martins, \& Ferreira, 2010). The compounds were identified by chromatographic comparisons with authentic standards. Quantification was based on the fluorescence signal response of each standard, using the IS (tocol) method and by using calibration curves obtained from commercial standards of each compound. The results were expressed in $\mu \mathrm{g}$ per $100 \mathrm{~g}$ of dry weight. 
Ergosterol. Sterols were extracted using a previously optimized multi-step procedure (Barreira, Oliveira, \& Ferreira, 2013). The analyses were performed in the HPLC equipment (described above) coupled to an ultraviolet Smartline $2500 \mathrm{UV}$ detector. Ergosterol was quantified by comparison of the area of its peak with the calibration curve obtained from a commercial standard. Cholecalciferol was used as internal standard. The results were expressed in $\mathrm{mg}$ per $\mathrm{g}$ of fat, $\mathrm{mg}$ per $100 \mathrm{~g}$ of dry weight and mg per $100 \mathrm{~g}$ of fresh weight.

\subsection{Evaluation of the antioxidant activity of different fractions and extracts of P. linteus}

The fractions/extracts were re-dissolved in water:DMSO at $20 \mathrm{mg} / \mathrm{mL}$. Successive dilutions from the stock solution were made and submitted to in vitro assays already described by Reis et al. (2012b). Four different assays were performed: reducing power, DPPH radical-scavenging activity, inhibition of $\beta$-carotene bleaching or $\beta$ carotene/linoleate assay and thiobarbituric acid reactive substances (TBARS) assay The sample concentrations $(\mathrm{mg} / \mathrm{mL})$ providing $50 \%$ of antioxidant activity or 0.5 of absorbance $\left(\mathrm{EC}_{50}\right)$ were calculated from the graphs of antioxidant activity percentages (DPPH, $\beta$-carotene/linoleate and TBARS assays) or absorbance at $690 \mathrm{~nm}$ (ferricyanide/Prussian blue assay) against sample concentrations. Trolox was used as a positive control.

2.5. Evaluation of the antimicrobial activity of different fractions and extracts of $P$.

\section{linteus}

The fractions/extracts were re-dissolved in 5\% solution of DMSO in distilled water at $100 \mathrm{mg} / \mathrm{mL}$. Successive dilutions were made from the stock solution and submitted to antibacterial and antifungal assays. 


\subsubsection{Antibacterial activity}

The assayed Gram-negative bacteria species were obtained from the Mycological laboratory, Department of Plant Physiology, Institute for biological research "Sinisa Stanković", University of Belgrade, Serbia. The antibacterial activity evaluation was performed according to a previously described methodology (Reis et al., 2013).

The minimum inhibitory (MIC) and minimum bactericidal (MBC) concentrations were determined by the microdilution method (Espinel-Ingroff, 2001). The minimum inhibitory concentrations (MICs) obtained from the susceptibility testing of various bacteria to tested extract/fraction were determined also by a colorimetric microbial viability assay based on reduction of INT color and compared with positive control for each bacterial strains (CSLI, 2006; Tsukatani et al., 2012). MBC was determined by serial sub-cultivation of $10 \mu \mathrm{L}$ into microplates containing $100 \mu \mathrm{L}$ of TSB. The lowest concentration that shows no growth after this sub-culturing was read as the MBC. Standard drugs, namely streptomycin and ampicillin were used as positive controls. DMSO (5\%) was used as negative control.

\subsubsection{Antifungal activity}

For the antifungal bioassays, the microfungi were obtained from the Mycological Laboratory, Department of Plant Physiology, Institute for Biological Research "Siniša Stanković", Belgrade, Serbia. The micromycetes were maintained on malt agar (MA) and the cultures were stored at $+4{ }^{\circ} \mathrm{C}$ and subcultured once a month (Booth, 1971). The microfungi cultures were established as previously described (Reis et al., 2013).

Minimum inhibitory concentrations (MICs) were determined by a serial dilution technique using 96-well microtitre plates. The fractions/extracts were dissolved in 5\% 
solution of DMSO and added to broth malt medium with fungal inoculum. The microplates were incubated for $72 \mathrm{~h}$ at $28^{\circ} \mathrm{C}$. The lowest concentrations without visible growth (at the binocular microscope) were defined as MIC. The minimum fungicidal concentrations (MFCs) were determined by serial subcultivation of $2 \mu \mathrm{L}$ in microtitre plates containing $100 \mu \mathrm{L}$ of malt broth per well and further incubation for $72 \mathrm{~h}$ at $28{ }^{\circ} \mathrm{C}$. The lowest concentration with no visible growth was defined as the MFC, indicating 99.5\% killing of the original inoculum. Bionazole and ketokonazole were used as positive controls. DMSO (5\%) was used as negative control.

\subsection{Evaluation of the anti-proliferative activity of the fractions and extracts of $P$.}

\section{linteus}

The fractions/extracts were re-dissolved in water:DMSO at $8 \mathrm{mg} / \mathrm{mL}$. Successive dilutions were made from the stock solution and tested against five human tumor cell lines: MCF-7 (breast adenocarcinoma), NCI-H460 (non-small cell lung cancer), HCT15 (colon carcinoma), HeLa (cervical carcinoma) and HepG2 (hepatocellular carcinoma). Cells were routinely maintained as adherent cell cultures (Reis et al., 2013). Cells were treated for $48 \mathrm{~h}$ with the diluted fraction/extract solutions. The adherent cells were fixed by adding cold 10\% trichloroacetic acid (TCA, $100 \mu \mathrm{L})$ and incubated for 60 min at $4{ }^{\circ} \mathrm{C}$. Plates were then washed with deionized water and dried; sulforhodamine B solution $(0.1 \%$ in $1 \%$ acetic acid, $100 \mu \mathrm{L})$ was then added to each plate well and incubated for $30 \mathrm{~min}$ at room temperature. Unbound SRB was removed by washing with $1 \%$ acetic acid. Plates were air dried, the bound SRB was solubilised with $10 \mathrm{mM}$ Tris $(200 \mu 1, \mathrm{pH} 7.4)$ and the absorbance was measured at $540 \mathrm{~nm}$ (Monks et al., 1991). The results were expressed in $\mathrm{GI}_{50}$ values (sample concentration that inhibited $50 \%$ of the net cell growth). Ellipticine was used as positive control. 


\subsection{Evaluation of hepatotoxicity of fractions and extracts of P. linteus}

An hepatic cell, designed as PLP2, was used (Abreu et al., 2011). Cells were treated for $48 \mathrm{~h}$ with the different diluted sample solutions and the same procedure described in the previous section for SRB assay was followed. The results were expressed in $\mathrm{GI}_{50}$ values (sample concentration that inhibited $50 \%$ of the net cell growth). Ellipticine was used as positive control.

\subsection{Statistical analysis}

All analyses (fractions and extracts) were performed in triplicate; each replicate was quantified also three times. Data were expressed as mean \pm standard deviation.

The fulfillment of the one-way ANOVA requirements, specifically the normal distribution of the residuals and the homogeneity of variance, was tested by means of the Shapiro-Wilk's (and also, due to the low size of samples, by direct observation of the normal Q-Q plots), and the Levene's tests, respectively. In the cases where statistical significance differences were identified, the dependent variable were compared using Tukey's honestly significant difference (HSD) or Tamhane's T2 multiple comparison tests, when homoscedasticity was verified or not, respectively.

\section{Results and Discussion}

The results obtained for macronutrients and lipophilic compounds quantification are presented in Table 1. The hydrophilic compounds were not tabled since any individual sugars or phenolic acids could be detected. Even in what concerns organic acids, oxalic acid was the only detected molecule $(0.295 \mathrm{~g} / 100 \mathrm{~g} \mathrm{dw})$. Carbohydrates were the major macronutrient $(95.4 \mathrm{~g} / 100 \mathrm{~g} \mathrm{dw})$, followed by protein $(2.8 \mathrm{~g} / 100 \mathrm{~g} \mathrm{dw})$ and ash $(1.3$ 
$\mathrm{g} / 100 \mathrm{~g} \mathrm{dw})$. As it is common on this kind of natural matrix, fat content was quite low $(0.49 \mathrm{~g} / 100 \mathrm{~g} \mathrm{dw})$. Despite this profile, energy was relatively high $(397.2 \mathrm{~g} / 100 \mathrm{~g} \mathrm{dw})$. The main fatty acids (FA) were palmitic acid (C16:0), linoleic acid (C18:2n6), oleic acid (C18:1n9) and stearic acid (C18:0) (Table 1), showing some similarity to previously published data on P. linteus from other location (Deng et al., 2011). Saturated fatty acids (SFA) predominated (58.3\% of total FA) over unsaturated fatty acids (UFA) (monounsaturated: $14.6 \%$ of total FA; polyunsaturated: $27.1 \%$ of total FA), but this is not relevant in terms of dietary intake, considering the low fat amounts of this species.

Regarding vitamin E profile, two isoforms were detected: $\alpha$ - and $\gamma$-tocopherol. Despite the limitation comprised by the fat content, the quantified vitamin $\mathrm{E}$ levels might be considered interesting, especially due to its role as peroxidation breaker or protectors of the integrity of lipid structures, since tocopherols are found in plasma, red cells and tissues (Burton \& Traber, 1990).

Ergosterol was also quantified, revealing low values $(2.73 \mathrm{mg} / 100 \mathrm{~g} \mathrm{dw})$ when compared with other wild and cultivated species (Barreira et al., 2013). Nevertheless, the presence of this vitamin precursor, known for health-promoting properties such as antioxidant, anti-inflammatory, antihyperlipidemic or immunomodulating activities (Barreira et al., 2013), is always relevant.

Considering the performed bioactivity assays, from the analysis of the results for the antioxidant potential (Table 2), it might be concluded that the methanolic extract of $P$. linteus revealed the lowest $\mathrm{EC}_{50}$ values for $\mathrm{DPPH}$ radical-scavenging activity (70 $\mu \mathrm{g} / \mathrm{mL})$, reducing power $(50.5 \mu \mathrm{g} / \mathrm{mL})$ and lipid peroxidation inhibition, either for $\beta$ carotene bleaching inhibition $(114 \mu \mathrm{g} / \mathrm{mL})$ as well as for TBARS inhibition $(8 \mu \mathrm{g} / \mathrm{mL})$. Among the assayed fractions, glucans showed the lowest antioxidant activity. The 
highest activity among assays was obtained for TBARS formation inhibition, while the worst values resulted from $\beta$-carotene bleaching inhibition. Nevertheless, $P$. linteus proved to have high potential for antioxidant purposes, since the obtained $\mathrm{EC}_{50}$ values were lower than those resulting from other wild edible species, which varied from 20.02 to $0.68 \mathrm{mg} / \mathrm{mL}$ (Pereira, Barros, Martins, \& Ferreira, 2012). In a previous study, $P$. linteus was shown to scavenge directly the DPPH radical over a concentration range of $10 \mu \mathrm{g} / \mathrm{mL}$ (30\% inhibition) to $300 \mu \mathrm{g} / \mathrm{mL}$ ( $85 \%$ inhibition), suggesting that the stable free radical scavenging activity of $P$. linteus is comparable to that of vitamin $\mathrm{C}$ (Song et al., 2003). In the same study, P. linteus and butylated hydroxyanisole, an inhibitor of lipid peroxidation (LPO), were evaluated for the inhibition of LPO in rat brain homogenate, initiated by $\mathrm{FeCl}_{2}$, showing that $P$. linteus reduced LPO in a concentrationdependent manner at concentrations ranging from 10 to $300 \mu \mathrm{g} / \mathrm{mL}$ with an $\mathrm{IC}_{50}$ of $48.45 \mu \mathrm{g} / \mathrm{mL}$ (Song et al., 2003), i.e., nearly 6 times weaker than the value herein reported using brain homogenates.

Concerning the antibacterial activity (Table 3), the methanolic extract also revealed the highest potential, considering MIC or MBC values, almost in all cases; moreover, it gave higher activity (in line with ethanolic extract) than ampicillin for all bacteria, and than streptomycin (except in the case of Staphylococcus aureus). The glucans fraction was the less effective against bacterial growth, except in the case of Salmonella typhimurium.

Regarding the antifungal activity (Table 4), the results were quite dissimilar, since methanolic extract had the highest activity only against Trichoderma viride (MIC = $0.0045 \mathrm{mg} / \mathrm{mL} ; \mathrm{MBC}=0.013 \mathrm{mg} / \mathrm{mL}$ ) and Penicillium ochrochloron $(\mathrm{MIC}=0.20$ $\mathrm{mg} / \mathrm{mL} ; \mathrm{MBC}=0.38 \mathrm{mg} / \mathrm{mL}$ ). Furthermore, the fractions with highest antifungal activity were glucans and triterpenoids (which were actually the least effective against 
bacteria), presenting lower MIC and MBC values than bifonazole and ketoconazole on Aspergillus versicolor, Aspergillus ochraceus, Trichoderma viride and Penicillium funiculosum. Aspergillus versicolor, Aspergillus ochraceus and Trichoderma viride (MIC $\leq 0.27 \mathrm{mg} / \mathrm{mL} ; \mathrm{MFC} \leq 0.77 \mathrm{mg} / \mathrm{mL}$, for all samples) were the fungal species with highest susceptibility to $P$. linteus.

The results obtained for cytotoxic activity in human tumor cell lines are presented in Table 5. The lowest $\mathrm{GI}_{50}$ values were obtained for ethanolic extract in all cell lines except $\mathrm{HepG}_{2}$, which proved to be more sensitive to the polysaccharidic fraction (97 $\mu \mathrm{g} / \mathrm{mL})$. Polysaccharides from $P$. linteus already exhibited antiproliferative effect in human hepatoma cells, specifically in Bel-7404 and in the same line used herein (OuYang et al., 2013). The ethanolic extract was particularly active on human nonsmall cell lung human (NCI-H460; $88 \mu \mathrm{g} / \mathrm{mL}$ ), colon (HCT-15; $62 \mu \mathrm{g} / \mathrm{mL}$ ) and cervical (HeLa; $61 \mu \mathrm{g} / \mathrm{mL}$ ) carcinoma cell lines. At the mentioned concentrations, the different fractions and extracts did not show toxicity against non-tumor liver primary cells (PLP2; $\mathrm{GI}_{50}>400 \mu \mathrm{g} / \mathrm{mL}$ ). The presented results clearly indicate that the antiproliferative activity of $P$. linteus might be significantly improved using an ethanol extract (certainly rich in triterpenoids and polyphenols) instead of polysaccharides fraction.

Overall, this study provided relevant knowledge regarding chemical and bioactive compounds profile of the medicinal mushroom Phellinus linteus. Despite the low number of detected hydrophilic compounds, $P$. linteus proved its high bioactivity, as measured by antioxidant, antibacterial and cytotoxic assays (in different human tumor cell lines). The whole methanolic and ethanolic extracts, and different fractions (polysaccharides, glucans and triterpenoids) were assayed, showing a differentiated 
mode of action regarding each of the evaluated bioactivities. The methanolic extract showed the highest antioxidant and antibacterial activities; glucan and triterpenoid fractions had the best antifungal activity; ethanolic extract gave the best results on cytotoxic activity, indicating that the bioactive compounds present (certainly triterpenoids and polyphenols) might act synergistically. The antimicrobial and cytotoxic activities of $P$. linteus justifies further studies to find antibacterial and antifungal agents as alternatives to synthetic chemicals applied in agriculture, food industry or pharmacy, as also to establish $P$. linteus as a promising source for developing new generation anticancer drugs.

\section{Acknowledgements}

The authors are grateful to Foundation for Science and Technology (FCT, Portugal) and COMPETE/QREN/EU for financial support to this work (research project PTDC/AGRALI/110062/2009, BPD/72802/2010 to J.C.M. Barreira and SFRH/BPD/68344/2010 to T.C. Calhelha) and to CIMO (strategic project PEst-OE/AGR/UI0690/2011). The authors also thank to Serbian Ministry of Education and Science for financial support (grant number 173032). Phellinus linteus fruiting body powder, crude polysaccharides

and triterpenoids were kind gifts of Amazing Grace Health Industries, Bangkok, Thailand.

\section{References}

Abreu, R.M.V., Ferreira, I.C.F.R., Calhelha, R.C., Lima, R.T., Vasconcelos, M.H., Adega, F., Chaves, R., \& Queiroz, M.J.R.P. (2011). Anti-hepatocellular carcinoma activity using human $\mathrm{HepG}_{2}$ cells and hepatotoxicity of 6-substituted methyl 3-aminothieno[3,2-b]pyridine-2-carboxylate derivatives: In vitro 
evaluation, cell cycle analysis and QSAR studies. European Journal of Medicinal Chemistry, 46, 5800-5806.

Alves, M.J., Ferreira, I.C.F.R., Dias, J., Teixeira, V., Martins, A., \& Pintado, M. (2012). A review on antimicrobial activity of mushroom (Basidiomycetes) extracts and isolated compounds. Planta Medica, 78, 1707-1718.

AOAC. (1995). Official methods of analysis $\left(16^{\text {th }}\right.$ Ed.). Arlington VA, USA: Association of Official Analytical Chemists.

Barreira, J.C.M., Oliveira, M.B.P.P., \& Ferreira, I.C.F.R. (2013). Development of a novel methodology for the analysis of ergosterol in mushrooms. Food Analytical Methods, doi: 10.1007/s12161-013-9621-9.

Barros, L., Pereira, C., \& Ferreira, I.C.F.R. (2013). Optimized analysis of organic acids in edible mushrooms from Portugal by ultra-fast liquid chromatography and photodiode array detection. Food Analytical Methods, 6, 309-316.

Booth, C. (1971). Fungal culture media. In JR Norris \& DW Ribbons (Eds.), Methods in microbiology (pp. 49-94). London and New York: Academic Press.

Burton, G.W., \& Traber, M.G. (1990). Vitamin E: antioxidant activity, biokinetics, and bioavailability. Annual Review of Nutrition, 10, 357-382.

Chen, W., Feng, L., Huang, Z., \& Su, H. (2012). Hispidin produced from Phellinus linteus protects against peroxynitrite-mediated DNA damage and hydroxyl radical generation. Chemico-Biological Interactions, 199, 137-142.

CLSI. Clinical and Laboratory Standards Institute. (2009). Methods for dilution antimicrobial susceptibility tests for bacteria that grow aerobically. Approved standard, 8th ed. CLSI publication M07-A8. Clinical and Laboratory Standards Institute, Wayne, PA. 
Deng, K., Zhang, Y., Ren, Z., Xie, L., Peng, W., \& Gan, B. (2011). Simultaneous determination of five fatty acids in Phellinus sp. by high-performance liquid chromatography with photodiode-array detection. Journal of Medicinal Plants Research, 5, 2816-2821.

Espinel-Ingroff, A. (2001). Comparation of the E-test with the NCCLS M38-P method for antifungal susceptibility testing of common and emerging pathogenic filamentous fungi. Journal of Clinical Microbiology, 39, 1360-1367.

Ferreira, I.C.F.R., Barros, L., \& Abreu, R.M.V. (2009). Antioxidants in wild mushrooms. Current Medicinal Chemistry, 16, 1543-1560.

Ferreira, I.C.F.R, Vaz, J.A., Vasconcelos, M.H., \& Martins, A. (2010). Compounds from wild mushrooms with antitumor potential. Anti-cancer Agents in Medicinal Chemistry, 10, 424-436.

Heleno, S.A., Barros, L., Sousa, M.J., Martins, A., \& Ferreira, I.C.F.R. (2010). Tocopherols composition of Portuguese wild mushrooms with antioxidant capacity. Food Chemistry, 119, 1443-1450.

Heleno, S.A., Barros, L., Martins, A., Queiroz, M.J.R.P., Santos-Buelga, C., \& Ferreira, I.C.F.R. (2012). Fruiting body, spores and in vitro produced mycelium of Ganoderma lucidum from Northeast Portugal: A comparative study of the antioxidant potential of phenolic and polysaccharidic extracts. Food Research International, 46, 135-140.

Huang, H.-Y., Chieh, S.-Y., Tso, T.K., Chien, T.-Y., Lin, H.-T., \& Tsai, Y.-C. (2011). Orally administered mycelial culture of Phellinus linteus exhibits antitumor effects in hepatoma cell-bearing mice. Journal of Ethnopharmacology, 133, 460466. 
Hur, J.-M., Yang, C.-H., Han, S.-H., Lee, S.-H., You, Y.-O., Park, J.-C., \& Kim, K.-J. (2004). Antibacterial effect of Phellinus linteus against methicillin-resistant Staphylococcus aureus. Fitoterapia, 75, 603-605.

Kim, S.-H., Kim, S.-H., Sung, J.-M., \& Harrington, T.C. (1999). Identification of Phellinus linteus by morphological characteristics and molecular analysis. Korean Journal of Mycology, 27, 337-340.

Kim, S.H., Lee, H.S., Lee, S., Cho, J., Ze, K., Sung, J., \& Kim, Y.C. (2004b). Mycelial culture of Phellinus linteus protects primary cultured rat hepatocytes against hepatotoxins. Journal of Ethnopharmacology, 95, 367-372.

Kim, S.-H., Song, Y.-S., Kim, S.-K., Kim, B.-C., Lim, C.-J., \& Park, E.-H. (2004a). Anti-inflammatory and related pharmacological activities of the $n-\mathrm{BuOH}$ subfraction of mushroom Phellinus linteus. Journal of Ethnopharmacology, 93, 141-146.

Kojima, K., Ohno, T., Inoue, M., Mizukami, H., \& Nagatsu, A. (2008). Phellifuropyranone A: a new furopyranone compound isolated from fruit bodies of wild Phellinus linteus. Chemical and Pharmaceutical Bulletin, 56, 173-175.

Lee, Y.S., Kang, Y.-H., Jung, J.-Y., Kang, I.-J., Han, S.-N., Chung, J.-S., Shin, H.-K., \& Lim, S.S. (2008). Inhibitory constituents of aldose reductase in the fruiting body of Phellinus linteus. Biological and Pharmaceutical Bulletin, 31, 765-768.

Maiti, S., Bhutia, S.K., Mallick, S.K., Kumar, A., Khadgi, N., \& Maiti, T.K. (2008). Antiproliferative and immunostimulatory protein fraction from edible mushrooms. Environmental Toxicology and Pharmacology, 26, 187-191.

Monks, A., Scudiero, D., Skehan, P., Shoemaker, R., Paull, K., Vistica, D., Hose, C., Langley, J., Cronise, P., \& Vaigro-Wolff, A. (1991). Feasibility of a high-flux 
anticancer drug screen using a diverse panel of cultured human tumor cell lines. Journal of the National Cancer Institute, 83, 757-766.

Nagatsu, A., Itoh, S., Tanaka, R., Kato, S., Haruna, M., Kishimoto, K., Hirayama, H., Goda, Y., Mizukami, H., \& Ogihara, Y. (2004). Identification of novel substituted fused aromatic compounds, meshimakobnol $\mathrm{A}$ and $\mathrm{B}$, from natural Phellinus linteus fruit body. Tetrahedron Letters, 45, 5931-5933.

OuYang, F., Wang, G., Guo, W., Zhang, Y., Xiang, W., \& Zhao, M. (2013). AKT signalling and mitochondrial pathways are involved in mushroom polysaccharideinduced apoptosis and G1 or S phase arrest in human hepatoma cells. Food Chemistry, 138, 2130-2139.

Pereira, E., Barros, L., Martins, A., \& Ferreira, I.C.F.R. (2012). Towards chemical and nutritional inventory of Portuguese wild edible mushrooms in different habitats. Food Chemistry, 130, 394-403.

Reis, F.S., Barros, L., Martins, A., \& Ferreira, I.C.F.R. (2012a). Chemical composition and nutritional value of the most widely appreciated mushrooms: an inter-species comparative study. Food and Chemical Toxicology, 50, 191-197.

Reis, F.S., Martins, A., Barros, L., \& Ferreira, I.C.F.R. (2012b). Antioxidant properties and phenolics profile of the most widely appreciated cultivated mushrooms: a comparative study between in vivo and in vitro samples. Food and Chemical Toxicology, 50, 1201-1207.

Reis, F.S., Barros, L., Calhelha, R.C., Ćirić, A., van Griensven, L.J.L.D., Soković, M., \& Ferreira, I.C.F.R. (2013). The methanolic extract of Cordyceps militaris (L.) Link fruiting body shows antioxidant, antibacterial, antifungal and antihuman tumor cell lines properties. Food and Chemical Toxicology, 62, 91-98. 
Song, K.-S., Li, G., Kim, J.-S., Jing, K., Kim, T.-D., Kim, J.-P., Seo, S.-B., Yoo, J.-K., Park, H.-D., Hwang, B.-D., Lim, K., \& Yoon, W.-H. (2011). Protein-bound polysaccharide from Phellinus linteus inhibits tumor growth, invasion, and angiogenesis and alters Wnt/beta-catenin in SW480 human colon cancer cells. BMC Cancer, 11, 307-327.

Song, W., Helsper, J.P.F.G., \& Van Griensven, L.J.L.D. (2008). Phenolic compounds present in medicinal mushroom extracts generate reactive oxygen species in human cells in vitro. International Journal of Medicinal Mushrooms, 10, 1-13.

Song, Y.S., Kim, S.H., Sa, J.H., Jin, C., Lim, C.J., \& Park, E.H. (2003). Antiangiogenic, antioxidant and xanthine oxidase inhibition activities of the mushroom Phellinus linteus. Journal of Ethnopharmacology, 88, 113-116.

Tsukatani, T., Suenaga, H., Shiga, M., Noguchi, K., Ishiyama, M., Ezoe, T., \& Matsumoto, K. (2012). Comparison of the WST-8 colorimetric method and the CLSI broth microdilution method for susceptibility testing against drug-resistant bacteria. Journal of Microbiological Methods, 90, 160-166.

Tu, J., Sun, H.-X., \& Ye, Y.-P. (2008). Immunomodulatory and antitumor activity of triterpenoid fractions from the rhizomes of Astilbe chinensis. Journal of Ethnopharmacology, 119, 266-271.

Wu, S.-J., Liaw, C.-C., Pan, S.-Z., Yang, H.-C., \& Ng, L.-T. (2013). Phellinus linteus polysaccharides and their immunomodulatory properties in human monocytic cells. Journal of Functional Foods, 5, 679-688.

Zhu, T., Guo, J., Collins, L., Kelly, J., Xiao, Z.J., Kim, S.H., \& Chen, C.Y. (2007). Phellinus linteus activates different pathways to induce apoptosis in prostate cancer cells. British Journal of Cancer, 96, 583-590. 
Table 1. Composition of Phellinus linteus in macronutrients and lipophilic compounds $($ mean $\pm \mathrm{SD})$.

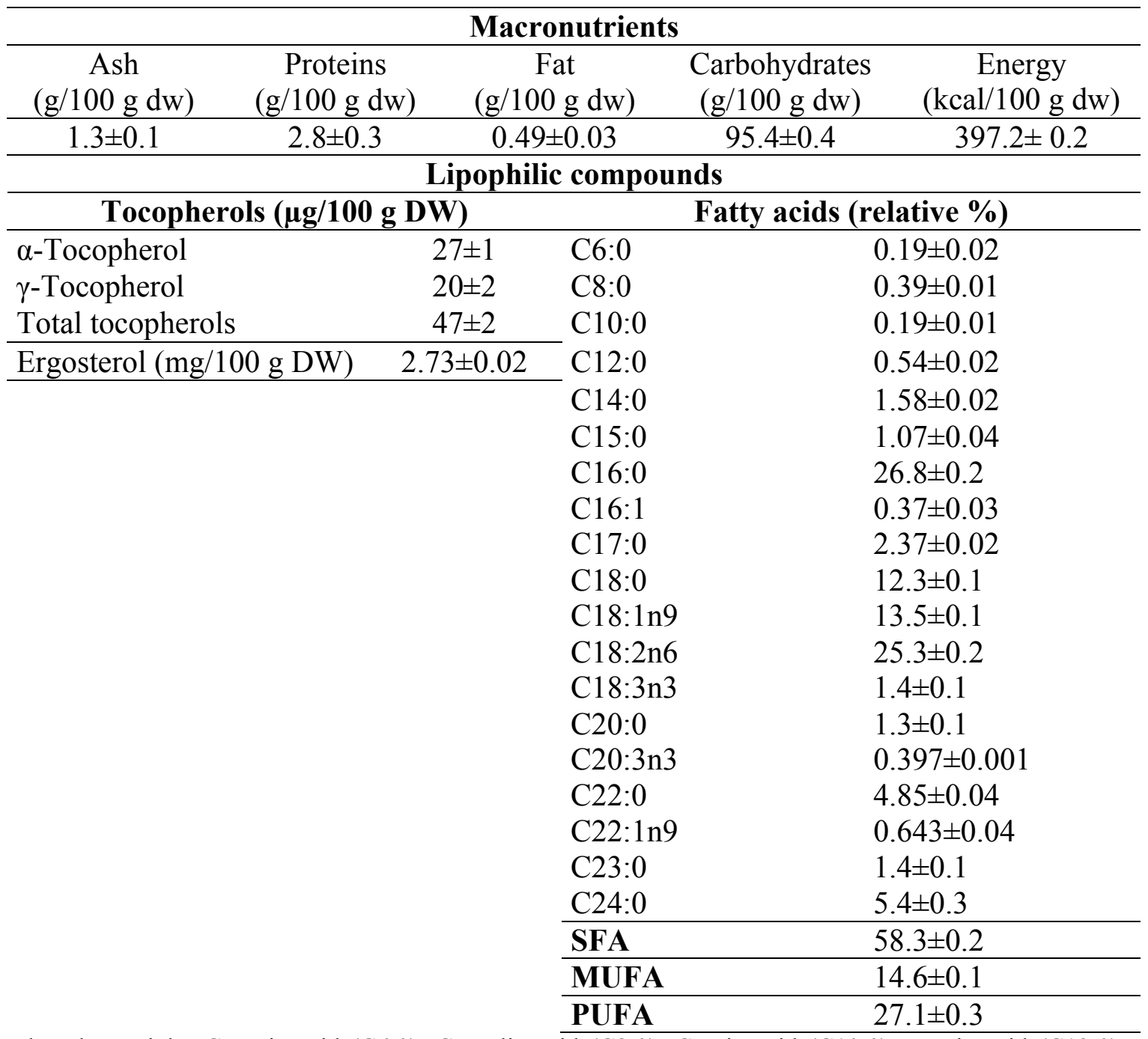

dw- dry weight. Caproic acid (C6:0); Caprylic acid (C8:0); Capric acid (C10:0); Lauric acid (C12:0); Myristic acid (C14:0); Pentadecanoic acid (C15:0); Palmitic acid (C16:0); Palmitoleic acid (C16:1); Heptadecanoic acid (C17:0); Stearic acid (C18:0); Oleic acid (C18:1n9c); Linoleic acid (C18:2n6c); $\alpha-$ Linolenic acid (C18:3n3); Arachidic acid (C20:0); Arachidonic acid methyl ester (C20:3n6); Behenic acid (C22:0); Erucic acid (C22:1n9); Tricosanoic acid (C23:0); Lignoceric acid (C24:0). SFA- saturated fatty acids; MUFA- monounsaturated fatty acids; PUFA- polyunsaturated fatty acids. 
Table 2. In vitro antioxidant properties of different fractions/extracts of Phellinus linteus (mean $\pm \mathrm{SD})^{1}$.

\begin{tabular}{|c|c|c|c|c|c|}
\hline & & \multirow{2}{*}{$\begin{array}{c}\text { DPPH } \\
\text { scavenging } \\
\text { activity }\end{array}$} & \multirow{2}{*}{$\begin{array}{c}\text { Ferricyanide/Prussian } \\
\text { blue assay }\end{array}$} & \multicolumn{2}{|c|}{ Lipid peroxidation inhibition } \\
\hline \multirow{6}{*}{$\mathrm{EC}_{50}(\mu \mathrm{g} / \mathrm{mL})$} & & & & $\begin{array}{c}\beta \text {-Carotene bleaching } \\
\text { inhibition }\end{array}$ & $\begin{array}{c}\text { TBARS formation } \\
\text { Inhibition }\end{array}$ \\
\hline & Polysaccharides & $340 \pm 20 \mathrm{~b}$ & $148 \pm 1 \mathrm{~b}$ & $1111 \pm 91 \mathrm{a}$ & $67 \pm 3 \mathrm{~b}$ \\
\hline & Glucans & $489 \pm 23$ a & $245 \pm 2$ a & $1103 \pm 117 \mathrm{a}$ & $122 \pm 5 \mathrm{a}$ \\
\hline & Triterpenoids & $129 \pm 3 \mathrm{~d}$ & $85 \pm 2 d$ & $163 \pm 8 \mathrm{c}$ & $20.5 \pm 0.2 \mathrm{~d}$ \\
\hline & Methanolic extract & $70 \pm 2 \mathrm{e}$ & $50.5 \pm 0.2 \mathrm{e}$ & $114 \pm 1 \mathrm{c}$ & $8 \pm 1 \mathrm{e}$ \\
\hline & Ethanolic extract & $222 \pm 4 \mathrm{c}$ & $120 \pm 2 \mathrm{c}$ & $419 \pm 25 \mathrm{~b}$ & $30 \pm 2 \mathrm{c}$ \\
\hline Homoscedasticity $^{2}$ & $p$-value & $<0.001$ & $<0.001$ & $<0.001$ & $<0.001$ \\
\hline One-way ANOVA ${ }^{3}$ & $p$-value & $<0.001$ & $<0.001$ & $<0.001$ & $<0.001$ \\
\hline Trolox (Standard) & & $43.03 \pm 1.71$ & $29.62 \pm 3.15$ & $2.63 \pm 0.14$ & $3.73 \pm 1.90$ \\
\hline
\end{tabular}

$\mathrm{EC}_{50}$ - fraction/extract concentration corresponding to $50 \%$ of antioxidant activity or 0.5 of absorbance for reducing power assay.

${ }^{1}$ Different letters in each column and for each fraction/extract indicate significant differences among mean values of each $\mathrm{EC}_{50}$.

${ }^{2}$ Homoscedasticity among fractions was tested by means of the Levene test: homoscedasticity, $p$-value $>0.05$; heteroscedasticity, $p$-value $<0.05$.

${ }_{p}^{3} p<0.05$ meaning that the mean value of the $\mathrm{EC}_{50}$ of at least one fraction/extract differs from the others (in this case multiple comparison tests were performed). 
Table 3. Antibacterial activity of different fractions/extracts of Phellinus linteus (mean $\pm \mathrm{SD}^{1}$ ).

\begin{tabular}{|c|c|c|c|c|c|c|c|c|c|}
\hline & & $\begin{array}{c}\text { Staphylococcus } \\
\text { aureus }\end{array}$ & $\begin{array}{c}\text { Bacillus } \\
\text { cereus }\end{array}$ & $\begin{array}{c}\text { Micrococcus } \\
\text { flavus }\end{array}$ & $\begin{array}{c}\text { Listeria } \\
\text { monocytogenes }\end{array}$ & $\begin{array}{c}\text { Pseudomonas } \\
\text { aeruginosa }\end{array}$ & $\begin{array}{c}\text { Salmonella } \\
\text { typhimurium }\end{array}$ & $\begin{array}{c}\text { Escherichia } \\
\text { coli }\end{array}$ & $\begin{array}{c}\text { Enterobacter } \\
\text { cloacae }\end{array}$ \\
\hline \multirow{5}{*}{$\mathrm{MIC}(\mathrm{mg} / \mathrm{mL})$} & Polysaccharides & $0.18 \pm 0.02 \mathrm{~b}$ & $0.16 \pm 0.01 \mathrm{~b}$ & $0.26 \pm 0.03 \mathrm{~b}$ & $0.27 \pm 0.02 \mathrm{~b}$ & $0.17 \pm 0.02 \mathrm{~b}$ & $0.52 \pm 0.02 \mathrm{a}$ & $0.47 \pm 0.02 \mathrm{~b}$ & $0.19 \pm 0.01 \mathrm{c}$ \\
\hline & Glucans & $0.25 \pm 0.01 \mathrm{a}$ & $0.26 \pm 0.01 \mathrm{a}$ & $1.4 \pm 0.1 \mathrm{a}$ & $0.47 \pm 0.02 \mathrm{a}$ & $0.27 \pm 0.02 \mathrm{a}$ & $0.27 \pm 0.02 \mathrm{~b}$ & $2.2 \pm 0.2 \mathrm{a}$ & $0.25 \pm 0.01 \mathrm{a}$ \\
\hline & Triterpenoids & $0.16 \pm 0.01 \mathrm{~b}$ & $0.17 \pm 0.02 \mathrm{~b}$ & $0.27 \pm 0.02 \mathrm{~b}$ & $0.27 \pm 0.02 \mathrm{~b}$ & $0.27 \pm 0.02 \mathrm{a}$ & $0.28 \pm 0.02 \mathrm{~b}$ & $0.25 \pm 0.04 \mathrm{c}$ & $0.23 \pm 0.02 \mathrm{~b}$ \\
\hline & Methanolic extract & $0.12 \pm 0.02 \mathrm{c}$ & $0.032 \pm 0.002 \mathrm{~d}$ & $0.048 \pm 0.002 \mathrm{~d}$ & $0.048 \pm 0.002 \mathrm{c}$ & $0.13 \pm 0.02 \mathrm{c}$ & $0.095 \pm 0.003 \mathrm{c}$ & $0.072 \pm 0.002 \mathrm{~d}$ & $0.048 \pm 0.002 \mathrm{e}$ \\
\hline & Ethanolic extract & $0.10 \pm 0.01 \mathrm{~d}$ & $0.077 \pm 0.002 \mathrm{c}$ & $0.15 \pm 0.01 \mathrm{c}$ & $0.022 \pm 0.002 \mathrm{~d}$ & $0.047 \pm 0.002 \mathrm{~d}$ & $0.12 \pm 0.02 \mathrm{c}$ & $0.17 \pm 0.02 \mathrm{~cd}$ & $0.12 \pm 0.02 \mathrm{~d}$ \\
\hline Homoscedasticity $^{2}$ & $p$-value & 0.049 & $<0.001$ & 0.001 & $<0.001$ & 0.001 & 0.002 & $<0.001$ & 0.009 \\
\hline One-way ANOVA ${ }^{3}$ & $p$-value & $<0.001$ & $<0.001$ & $<0.001$ & $<0.001$ & $<0.001$ & $<0.001$ & $<0.001$ & $<0.001$ \\
\hline \multirow{5}{*}{$\mathrm{MBC}(\mathrm{mg} / \mathrm{mL})$} & Polysaccharides & $0.40 \pm 0.04 \mathrm{~b}$ & $0.27 \pm 0.02 \mathrm{~b}$ & $0.47 \pm 0.02 \mathrm{~b}$ & $0.47 \pm 0.02 \mathrm{~b}$ & $0.38 \pm 0.02 \mathrm{~b}$ & $1.03 \pm 0.03 \mathrm{~b}$ & $1.1 \pm 0.1 \mathrm{~b}$ & $0.43 \pm 0.02 \mathrm{~b}$ \\
\hline & Glucans & $0.48 \pm 0.02 \mathrm{a}$ & $0.48 \pm 0.02 \mathrm{a}$ & $2.7 \pm 0.2 \mathrm{a}$ & $1.0 \pm 0.1 \mathrm{a}$ & $2.1 \pm 0.3 \mathrm{a}$ & $2.1 \pm 0.3 \mathrm{a}$ & $2.4 \pm 0.2 \mathrm{a}$ & $2.2 \pm 0.2 \mathrm{a}$ \\
\hline & Triterpenoids & $0.23 \pm 0.02 \mathrm{c}$ & $0.27 \pm 0.02 \mathrm{~b}$ & $0.52 \pm 0.02 \mathrm{~b}$ & $0.50 \pm 0.03 \mathrm{~b}$ & $0.50 \pm 0.03 \mathrm{~b}$ & $0.50 \pm 0.03 \mathrm{c}$ & $0.52 \pm 0.02 \mathrm{c}$ & $0.27 \pm 0.02 \mathrm{c}$ \\
\hline & Methanolic extract & $0.19 \pm 0.01 \mathrm{~d}$ & $0.043 \pm 0.002 \mathrm{~d}$ & $0.13 \pm 0.02 \mathrm{c}$ & $0.18 \pm 0.02 \mathrm{~d}$ & $0.17 \pm 0.02 \mathrm{c}$ & $0.19 \pm 0.01 \mathrm{~d}$ & $0.12 \pm 0.01 \mathrm{~d}$ & $0.104 \pm 0.004 \mathrm{~d}$ \\
\hline & Ethanolic extract & $0.22 \pm 0.02 \mathrm{~cd}$ & $0.10 \pm 0.01 \mathrm{c}$ & $0.18 \pm 0.02 \mathrm{c}$ & $0.40 \pm 0.03 \mathrm{c}$ & $0.12 \pm 0.02 \mathrm{c}$ & $0.37 \pm 0.02 \mathrm{c}$ & $0.23 \pm 0.02 \mathrm{~d}$ & $0.22 \pm 0.02 \mathrm{~cd}$ \\
\hline Homoscedasticity $^{2}$ & $p$-value & $<0.001$ & $<0.001$ & $<0.001$ & 0.018 & $<0.001$ & $<0.001$ & $<0.001$ & $<0.001$ \\
\hline One-way ANOVA $^{3}$ & $p$-value & $<0.001$ & $<0.001$ & $<0.001$ & $<0.001$ & $<0.001$ & $<0.001$ & $<0.001$ & $<0.001$ \\
\hline \multirow{2}{*}{$\mathrm{MIC}(\mathrm{mg} / \mathrm{mL})$} & Ampicillin & $0.29 \pm 0.03$ & $0.23 \pm 0.03$ & $0.23 \pm 0.02$ & $0.37 \pm 0.01$ & $0.72 \pm 0.02$ & $0.36 \pm 0.01$ & $0.21 \pm 0.03$ & $0.33 \pm 0.03$ \\
\hline & Streptomycin & $0.040 \pm 0.004$ & $0.09 \pm 0.01$ & $0.15 \pm 0.01$ & $0.16 \pm 0.01$ & $0.13 \pm 0.03$ & $0.17 \pm 0.01$ & $0.15 \pm 0.02$ & $0.25 \pm 0.01$ \\
\hline \multirow{2}{*}{$\mathrm{MBC}(\mathrm{mg} / \mathrm{mL})$} & Ampicillin & $0.38 \pm 0.01$ & $0.38 \pm 0.01$ & $0.37 \pm 0.01$ & $0.47 \pm 0.02$ & $1.24 \pm 0.01$ & $0.47 \pm 0.02$ & $0.45 \pm 0.03$ & $0.68 \pm 0.05$ \\
\hline & Streptomycin & $0.09 \pm 0.01$ & $0.16 \pm 0.01$ & $0.32 \pm 0.02$ & $0.33 \pm 0.03$ & $0.32 \pm 0.02$ & $0.33 \pm 0.01$ & $0.33 \pm 0.02$ & $0.50 \pm 0.01$ \\
\hline
\end{tabular}

MIC- minimum inhibitory concentration; MBC- minimum bactericidal concentration.

${ }^{1}$ Different letters in each column and for each fraction/extract indicate significant differences among mean values of each MIC or each MBC.

${ }^{2}$ Homoscedasticity among fractions/extracts was tested by means of the Levene test: homoscedasticity, $p$-value $>0.05$; heteroscedasticity, $p$-value $<0.05$.

${ }^{3} p<0.05$ meaning that the mean value of MIC or MBC of at least one fraction/extract differs from the others (in this case multiple comparison tests were performed). 
Table 4. Antifungal activity of different fractions/extracts of Phellinus linteus (mean $\pm \mathrm{SD}^{1}$ ).

\begin{tabular}{|c|c|c|c|c|c|c|c|c|c|}
\hline & & $\begin{array}{l}\text { Aspergillus } \\
\text { fumigatus }\end{array}$ & $\begin{array}{l}\text { Aspergillus } \\
\text { versicolor }\end{array}$ & $\begin{array}{c}\text { Aspergillus } \\
\text { ochraceus }\end{array}$ & $\begin{array}{l}\text { Aspergillus } \\
\text { niger }\end{array}$ & $\begin{array}{l}\text { Trichoderma } \\
\text { viride }\end{array}$ & $\begin{array}{l}\text { Penicillium } \\
\text { funiculosum }\end{array}$ & $\begin{array}{l}\text { Penicillium } \\
\text { ochrochloron }\end{array}$ & $\begin{array}{l}\text { Penicillium } \\
\text { verrucosum }\end{array}$ \\
\hline \multirow{5}{*}{$\mathrm{MIC}(\mathrm{mg} / \mathrm{mL})$} & Polysaccharides & $0.51 \pm 0.04 \mathrm{a}$ & $0.18 \pm 0.05 \mathrm{~b}$ & $0.13 \pm 0.03 \mathrm{c}$ & $0.47 \pm 0.02 \mathrm{~b}$ & $0.27 \pm 0.02 \mathrm{a}$ & $0.11 \pm 0.01 \mathrm{c}$ & $0.46 \pm 0.04 \mathrm{a}$ & $0.27 \pm 0.02 \mathrm{c}$ \\
\hline & Glucans & $0.25 \pm 0.02 \mathrm{c}$ & $0.060 \pm 0.001 \mathrm{~d}$ & $0.12 \pm 0.01 \mathrm{c}$ & $0.22 \pm 0.02 \mathrm{c}$ & $0.11 \pm 0.01 \mathrm{bc}$ & $0.11 \pm 0.01 \mathrm{c}$ & $0.27 \pm 0.02 \mathrm{c}$ & $0.27 \pm 0.02 \mathrm{c}$ \\
\hline & Triterpenoids & $0.24 \pm 0.04 \mathrm{c}$ & $0.12 \pm 0.02 \mathrm{c}$ & $0.13 \pm 0.02 \mathrm{c}$ & $0.77 \pm 0.03 \mathrm{a}$ & $0.10 \pm 0.01 \mathrm{c}$ & $0.12 \pm 0.02 \mathrm{c}$ & $0.23 \pm 0.02 \mathrm{~d}$ & $0.42 \pm 0.02 \mathrm{~b}$ \\
\hline & Methanolic extract & $0.42 \pm 0.02 \mathrm{~b}$ & $0.16 \pm 0.04 \mathrm{bc}$ & $0.18 \pm 0.02 \mathrm{~b}$ & $0.74 \pm 0.04 \mathrm{a}$ & $0.0045 \pm 0.0004 \mathrm{~d}$ & $0.20 \pm 0.01 \mathrm{~b}$ & $0.20 \pm 0.01 \mathrm{~d}$ & $0.44 \pm 0.04 \mathrm{~b}$ \\
\hline & Ethanolic extract & $0.39 \pm 0.03 \mathrm{~b}$ & $0.22 \pm 0.02 \mathrm{a}$ & $0.22 \pm 0.02 \mathrm{a}$ & $0.77 \pm 0.02 \mathrm{~b}$ & $0.12 \pm 0.02 \mathrm{~b}$ & $0.75 \pm 0.04 \mathrm{a}$ & $0.35 \pm 0.03 \mathrm{~b}$ & $0.85 \pm 0.04 \mathrm{a}$ \\
\hline Homoscedasticity $^{2}$ & $p$-value & $<0.001$ & $<0.001$ & 0.002 & 0.022 & $<0.001$ & $<0.001$ & 0.002 & 0.001 \\
\hline One-way ANOVA 3 & $p$-value & $<0.001$ & $<0.001$ & $<0.001$ & $<0.001$ & $<0.001$ & $<0.001$ & $<0.001$ & $<0.001$ \\
\hline \multirow{5}{*}{$\mathrm{MFC}(\mathrm{mg} / \mathrm{mL})$} & Polysaccharides & $1.1 \pm 0.1 \mathrm{a}$ & $0.50 \pm 0.03 \mathrm{a}$ & $0.46 \pm 0.03 \mathrm{~b}$ & $1.4 \pm 0.1 \mathrm{~b}$ & $0.44 \pm 0.04 \mathrm{a}$ & $0.45 \pm 0.04 \mathrm{c}$ & $1.0 \pm 0.1 \mathrm{a}$ & $1.0 \pm 0.1 \mathrm{~b}$ \\
\hline & Glucans & $0.47 \pm 0.02 \mathrm{c}$ & $0.12 \pm 0.01 \mathrm{~d}$ & $0.27 \pm 0.02 \mathrm{c}$ & $0.45 \pm 0.04 \mathrm{c}$ & $0.26 \pm 0.02 \mathrm{~b}$ & $0.27 \pm 0.02 \mathrm{e}$ & $0.47 \pm 0.02 \mathrm{c}$ & $0.46 \pm 0.04 \mathrm{~d}$ \\
\hline & Triterpenoids & $0.45 \pm 0.04 \mathrm{c}$ & $0.44 \pm 0.03 \mathrm{~b}$ & $0.44 \pm 0.03 \mathrm{~b}$ & $1.4 \pm 0.1 \mathrm{~b}$ & $0.18 \pm 0.02 \mathrm{~d}$ & $0.85 \pm 0.04 \mathrm{~b}$ & $0.40 \pm 0.03 \mathrm{~d}$ & $0.78 \pm 0.02 \mathrm{c}$ \\
\hline & Methanolic extract & $0.79 \pm 0.05 \mathrm{~b}$ & $0.37 \pm 0.02 \mathrm{c}$ & $0.42 \pm 0.02 \mathrm{~b}$ & $1.4 \pm 0.1 \mathrm{~b}$ & $0.013 \pm 0.002 \mathrm{e}$ & $0.38 \pm 0.02 \mathrm{~d}$ & $0.38 \pm 0.02 \mathrm{~d}$ & $0.77 \pm 0.02 \mathrm{c}$ \\
\hline & Ethanolic extract & $0.83 \pm 0.03 \mathrm{~b}$ & $0.43 \pm 0.02 \mathrm{~b}$ & $0.77 \pm 0.05 \mathrm{a}$ & $2.2 \pm 0.2 \mathrm{a}$ & $0.23 \pm 0.02 \mathrm{c}$ & $1.4 \pm 0.1 \mathrm{a}$ & $0.78 \pm 0.02 \mathrm{~b}$ & $1.4 \pm 0.1 \mathrm{a}$ \\
\hline Homoscedasticity $^{2}$ & $p$-value & $<0.001$ & 0.129 & 0.009 & 0.022 & 0.002 & $<0.001$ & 0.001 & $<0.001$ \\
\hline One-way ANOVA $^{3}$ & $p$-value & $<0.001$ & $<0.001$ & $<0.001$ & $<0.001$ & $<0.001$ & $<0.001$ & $<0.001$ & $<0.001$ \\
\hline \multirow{2}{*}{$\mathrm{MIC}(\mathrm{mg} / \mathrm{mL})$} & Bifonazole & $0.12 \pm 0.02$ & $0.08 \pm 0.01$ & $0.12 \pm 0.02$ & $0.13 \pm 0.02$ & $0.13 \pm 0.02$ & $0.24 \pm 0.04$ & $0.15 \pm 0.04$ & $0.10 \pm 0.01$ \\
\hline & Ketoconazole & $0.20 \pm 0.03$ & $0.15 \pm 0.04$ & $1.5 \pm 0.1$ & $0.22 \pm 0.02$ & $1.0 \pm 0.1$ & $0.15 \pm 0.04$ & $2.7 \pm 0.2$ & $0.19 \pm 0.02$ \\
\hline \multirow{2}{*}{$\operatorname{MFC}(\mathrm{mg} / \mathrm{mL})$} & Bifonazole & $0.17 \pm 0.02$ & $0.16 \pm 0.03$ & $0.20 \pm 0.01$ & $0.25 \pm 0.03$ & $0.20 \pm 0.01$ & $0.23 \pm 0.02$ & $0.22 \pm 0.02$ & $0.20 \pm 0.03$ \\
\hline & Ketoconazole & $0.49 \pm 0.01$ & $0.44 \pm 0.04$ & $2.2 \pm 0.2$ & $0.52 \pm 0.02$ & $0.8 \pm 0.2$ & $0.52 \pm 0.05$ & $3.6 \pm 0.1$ & $0.30 \pm 0.03$ \\
\hline
\end{tabular}

MIC- minimum inhibitory concentration; MFC- minimum fungicidal concentration.

${ }^{1}$ Different letters in each column and for each fraction/extract indicate significant differences among mean values of each MIC or each MFC.

${ }^{2}$ Homoscedasticity among fractions/extracts was tested by means of the Levene test: homoscedasticity, $p$-value $>0.05$; heteroscedasticity, $p$-value $<0.05$.

${ }^{3} p<0.05$ meaning that the mean value of MIC or MFC of at least one fraction/extract differs from the others (in this case multiple comparison tests were performed). 
Table 5. Cytotoxic activity of different fractions/extracts of Phellinus linteus against human tumor cell lines and non-tumor liver primary cells $\left(\right.$ mean $\left.\pm \mathrm{SD}^{1}\right)$.

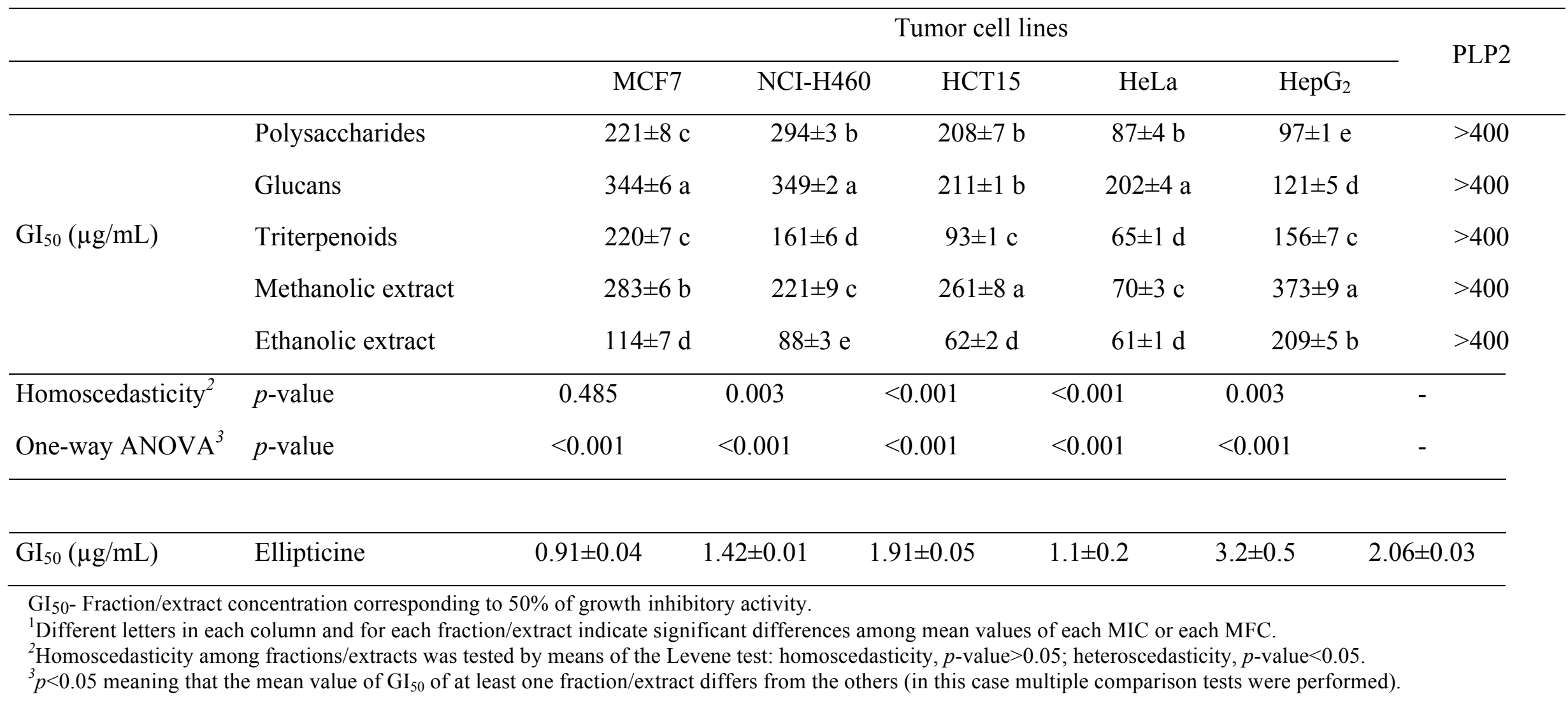

